\title{
Debt Theories in Islamic Commercial Transactions and Their Implications for the Islamic Capital Market
}

\author{
Auwal Adam Saad and \\ Syed Musa Bin Syed Jaafar Alhabshi \\ International Islamic University Malaysia (IIUM)
}

\begin{abstract}
There are two different approaches to the prophetic concern regarding debt acquisition and the related rulings. The Prophet (peace be upon him) was recorded as having discouraged debt while other verbal traditions provided guidelines on how to manage debt in a socially responsible manner. This paper aims to analyse these two contrary views according to the Maqasid Shariah and look at how this has impacted juristic rulings. Furthermore, the paper reviews classical fiqh theories on debt, sale of debt, alMuqassah, Suftajah, Hawalah, and Ibra. The paper also reviews the theoretical perspective on the sale of debt according to the understanding of Islamic scholars across the schools of Islamic Jurisprudence which has a substantial impact on the contemporary practices in Islamic banking and the Islamic capital market.
\end{abstract}

Keywords: Debt theories; Sale of Debt; Islamic Banking; Hawalah; Ibra; Suftajah; Muqassah 


\section{Introduction}

The word Dayn (Debt) is an Arabic word developed from the same root as (Din) meaning submissiveness or disgrace. Dayn in Islamic Jurisprudence refers to debt, financial liability or monetary obligation. This definition includes all assets, including intangible assets such as property rights and music royalties. Prophet Muhammad (peace be upon him) discouraged the practice of debt. The Prophet said: "The soul of the believer is held hostage by his debt in his grave until it is paid off' (narrated by alTirmidhi, 1078). In another hadith, the Prophet said: "Your companion is being detained by his debt"' (Sunan Abi Dawud, 3341).

However, it is important to point out that debt is not prohibited in Islam. Islamic teachings advocate protection of the poor and the vulnerable against economic exploitation. Muslims are not allowed to benefit from earning interest (riba) because interest charges would deepen the debt burden. To prevent serious indebtedness, Islam prohibits interest-bearing loan and advocates responsible lending. Jabir bin Abdullah narrated: "I went to the Prophet while he was in the Mosque. After the Prophet told me to pray two rakat, he repaid me the debt he owed me and gave me an extra amount" (Sahih al-Bukhari, Book 43, Hadith 10). This hadith shows that the Prophet also took loans in his lifetime and repaid the debt including more than the principal amount borrowed.

It was narrated by Abu Huraira that the Messenger of Allah borrowed a young camel from a man and then the man came to get his camel back. The Prophet asked his companions to repay him. They looked for a camel of the same age but found nothing but a camel one year older. The Prophet told them to give it to him and said, "The best amongst you is he who pays his debts in the most handsome manner" (Sahih alBukhari, Book 43, Hadith 6). This hadith indicates that the Prophet repaid his debt with more than the principal amount he owed to show his gratitude. In short, interestbearing loans are prohibited, but making an additional principal payment is considered good practice. These two different attitudes towards debt inspire a number of debt theories in Islamic finance and banking, which will be discussed in detail in this paper.

\section{Understanding the concept of Dayn in Shari'ah}

To understand the concept of debt in Shari'ah, it is necessary to go back to the reported prophetic traditions on debt. Some traditions were in support of debt, while some other traditions were not. In the following paragraphs we will be evaluating such traditions for better understanding. One hadith recorded: "if you were patient and sincere and always fought facing the enemy and never turning your back upon him, (all your lapses would be forgiven) except debt" (Sahih Muslim 1885 a). This hadith indicates that Islam takes debt seriously and warns against it. Similarly, another hadith recorded that: "We were with the Prophet at a funeral, and he said: 'I there anyone from banu so and so here? He said this three times. Then a man stood up, and he said to him: 'What kept you form answering the first two times? I am not going to say anything but good to you, so and so (mentioning the name of a man from among them) has died and he is being detained (from entering Paradise) because of his debt"

International Journal of Management and Applied Research, 2019, Vol. 6, No. 4 
(Sunan an-Nasa'i,4685). Umar bin Khattab was recorded as saying "Beware of a Debt, because it always states with pain and ends with conflict" (Muwatta Malik, Book 37, Hadith 1465). These records show that debt obligation is discouraged and unpaid debt disqualifies any person for admission to jannah (paradise).

However, some traditions were reported to have supported debt acquisition and indebtedness. Al-Amash narrated: "the Prophet of Allah bought food items from a Jew in Medina, and gave away his war-armour as security" (Sahih al-Bukhari, Book 43, Hadith 2). Imam Ibn Abdul bar (1999) said that borrowing is reasonable if the borrower has the intention of repaying the dept, however if his intention is not to repay then it is prohibited. It was narrated to Isla'il bin Ibrahim bin 'Abdullah bin Abi Rabi'ah, by his father, that his grandfather said: "The Prophet borrowed forty thousand from me, then some wealth came to him, and he paid me back and said: May Allah bless your family and your wealth for you: the reward for lending is praise and repayment" (Sunan an-Nasa'i, Book 44, Hadith 235). These are explicit evidence for the permissibility of debt and repayment.

To sum up, for debt to be permissible in Islamic law, the following conditions must be met: first, the borrower must have the intention of repaying the debt; second, the borrower has the ability to repay it; and lastly, the loan should not be funded by prohibited industries such as gambling and alcohol.

\section{Sale of Debt in Shari'ah law}

Sale of debt (Bai Dayn) is a sale of debt either to the debtor himself or to a third party, to be repaid immediately or for deferred payment. There are divergent rulings among Islamic scholars on the permissibility of Bai Dayn. Islamic jurists agree that the sale of debt at its equivalent value is permissible, if the payment is made on the spot. Deferred payment for the sale of debt is not widely accepted by Islamic scholars because it involves riba (interest) and gharar (uncertainty). As a general rule, it is not permitted to sell a commodity which is not in the possession of the seller. Such a transaction is uncertain (gharar) because the buyer cannot be certain that he or she will receive the commodity on time or receive it at all. Where a person has bought something from a seller by instalments, and if the buyer is unable to pay on time, the seller may resell the commodity with additional charges. Such a transaction is considered as riba-based because it involves "increase the time in exchange with an increase of price" or "time value of money".

The sale of debt to a third party, on the other hand, is controversial. The Hanafi scholars are of the opinion that delivery is one of the essentials in an Islamic contact. The contract of sale of debt to a third party is not deliverable so it is not approved under the Hanafi and Hanbalis School because the creditor is not in a position to ensure delivery of the debt can be made to the third party (Imam Al-Kasani, 2005). However, the Shafii School allowed the sale of a confirmed debt because these debts are deemed deliverable without impediments. They accepted it on the basis that the possibility to repay or deliver is strongly anticipated. The Maliki School also accepted the sale of debt to a third party under three main conditions: first, it should be free from gharar and riba; second, it should not be based on future payments to avoid

International Journal of Management and Applied Research, 2019, Vol. 6, No. 4 
selling debt for debt, and third, the fee should be equivalent to the debt sold to avoid riba in sales. Additionally, debt under conflict does not qualify according to these conditions, nor does the debt owed by a bankrupt, and there should not be aggression between debtor and debt purchaser (Jami at-Tirmidhi, Book 14, Hadith 112).

\subsection{Al-Muqassah}

The word Al-Muqassah in Arabic means equality and equivalence, some Islamic scholars define it as a debt waver based on offset on conditions. Another definition credited to Ibn al-Qiyyim is to exchange a debt with another similar debt with the same value (Ibn al-Qayyim al-Jawziyyah, 1973). The doctrine of Al-Muqassah is accepted based on the consensus of scholars regarding the reported tradition of Ibn Umar, which was mentioned earlier, describing his transactions with different currencies. The permissibility of setting off payment or any other liabilities can be found in the answer given by the Prophet: "It is an act of oppression on the part of a person to procrastinate in fulfilling his obligation; if the repayment of a debt due to any of you is undertaken by a rich person, you should agree to the substitution" (Abu Hurairah, Book 18, Hadith 1611).

Al-Muqassah should not occur on property "ain" and not in an exchange between debt and property. Al-Muqassah is sub-divided into two types: al-Muqassah al-Jabriyyah and al-Muqassah al-Ittafaqiyyah, which will be discussed in the following sections.

\subsubsection{Al-muqssah Al-Jabriyyah}

This type of al-Muqassah is automatically waving the debt liability of two different debts indebted by two different people to each other, but this has to be with similar value, similar amount and similar repayment duration and has no request or intemperance from any of the contracting parties. This type of Al-Muqassah is a brain child of Hanafi and Hanbali Schools of jurisprudence. The Maliki School did not favour this type of al-Muqassah unless there is a prior agreement between the parties involved. Four different rules of al-Muqassah can be noted, the first is debt harmony, which means the debtors must become indebted to each other, meaning that every one of them should have a debt to settle for his partner. Another condition is the similarity of the debts under which the debts must be similar in kind, type and maturity. If the maturity is not the same, then al-Muqassah could not be accepted according to the Hanafi interpretation (Bilal and Meera, 2015).

The Maliki, Hanafi and Shafii Schools allow for a difference in currency (Bhala, 2011). The three Schools hold that repaying a loan in a different currency is permissible, if the amount of debt remains unchanged. The Hanbali School is less flexible in this matter. The rationale given for this position is that, this repayment of debt is actually selling the currency for another currency at a future date, which is equivalent to riba. The Islamic prohibition of riba does not recognize the time value of money.

\subsubsection{Al-Muqassah Al-Ittifaqiyyah}

This type of al-Muqassah is regarded as Al-Muqassah that occurrs based on agreement. It is another type of al-muqassah which is based on consensus of the

International Journal of Management and Applied Research, 2019, Vol. 6, No. 4 
involved parties; this type of muqassah is permissible if it does not violate any Shari'ah ruling, such as prohibition of riba and gharar. In al-ittifaqiyyah, both parties must be in debt to each other and discharge their contractual obligations to each other with mutual consent (Bilal and Meera, 2015).

\subsection{Al-Hawalah}

The Arabic meaning of al-Hawala is transfer. Hawalah is technically a transfer of debt liability to another. Generally, the scholars of Islamic jurisprudence have unanimously agreed upon the acceptability of al-Hawalah, this is based on various reported Hadith traditions, analogy and consensus. Al-hawalah is similar to al-kafalah (guarantee) because the grantor and transferor play an important role in facilitating trade across borders (Suhaimi et al., 2016), and both methods facilitate debt liability reimbursement (Ibn Qudamah, 1968).

There is a disagreement between scholars on the acceptability of al-hawalah (Al Raisi et al., 2016). Scholars from the Maliki, Shafii, Zahiri and some of the Hanafi schools are of the opinion that al-hawalah is a sale of debt for debt, however it is permissable and it is an exception from the general rule, the legality comes because it is based on the needs of people and it is regarded as a special sympathy of the lawgiver which facilitates its acceptance. Sheik Ibn Rushd of the Maliki school demonstrated that, alhawalah is a valid contract and exempted from bay dayn bi dayn (Imam Ibn Rushd, 2004). However, according to Sheikul Islam bin Taimiyah, Ibnul Qiyyim and some Shafii scholars, al-hawala is not a sale contract and it is a transferring of rights and that is why Prophet Muhammad did not indicate a sale contract in the hadith, what he mentions was only the transfer of debt, he said: "Procrastination (delay) in paying debts by a wealthy man is injustice. So, if your debt is transferred from your debtor to a rich debtor, you should agree" (Sahih al-Bukhari, Book 38, Hadith 1).

The Hanbali and their counterparts from Hanafi Madhab have a different opinion which indicates that al-hawalah is a dependent contract and permissible, as al-hawalah can be applied for special needs. However, according these schools al-hawalah is like a contract of sale but technically is not a sale contract. It also resembles kafalah "guarantee" and agency contracts (Suhaimi et al., 2016). Therefore, the rules of alhawalah vary according to the Islamic contract. The Hanbali school of jurisprudence made it compulsory for the debt owner to accept and comply with the transfer, their opinion is based on the hadith "if your debt is transferred from your debtor to a rich debtor, you should agree" (Sahih al-Bukhari, Book 38, Hadith 1) and the prophet's instruction here is mandatory. However, the Hanafi School regarded it as a permissible act, arguing that there are, among the wealthy, people who are defaulting for no reason and manipulating people's rights and debt repayment. The Shafii and Maliki and most scholars regarded al-Hawalah acceptance as recommended "Mustahab" (Ibn Qudamah, 1968).

\subsection{Suftajah}

Suftajah is a Persian word used in Arabic, the original meaning of Suftajah is regulation, or something regulated. Sifat and Mohamad (2018) refer Suftajah as " $a$ debt transfer transaction popularized in Abbasi dynasty, whereby a debtor nominates

International Journal of Management and Applied Research, 2019, Vol. 6, No. 4 
an agent who owes him a debt, which is then repaid in a pre-determined amount to someone else, to whom first person owes a debt" (p. 8) and they describe Suftajah as "the precursor of the bill of exchange" (p. 16). Suftajah combined the features of travellers' cheques and letters of credit. Originally developed for loan merchants, Suftajah eliminates the risk of losing money during transport because the merchants can repay the loan in a different place; moreover, the loan can be paid to the original lender or to a third party (Ray, 1997). Suftajah can be divided into two types: pure debt and transfer of debt. Pure debt, qardun mahadh, is aimed at paying the debt liability to the owner. Whereas suftajah based on hawalah transfer includes the transfer of debt via method of repayment by transfer of liability to a lender residing in the town of a debtor owner.

The scholars of Islamic jurisprudence have different opinions regarding the concept of Suftajah. The first opinion is that Suftajah is not applicable if the payment settlement in another town is based on a condition agreed between the parties. The reason of prohibition here, according the scholars, was because of the utility and the advantage taken during the debt contract and any utility in the debt contract is unlawful (Ray, 1997). However, if there is a condition in the contract then it is permissible. Because giving out charity of the utility by a debtor to the lender is of good performance and it is recommended by the Prophet, which is also recognised by the Hanafi and Shafii schools of jurisprudence. Second, the concept of Suftajah is not applicable except if it is necessary, where for example if a debtor did not practice Suftajah it may lead to his loss or harm his business and wealth, then it is allowable based on Maslahah Mursalah for wealth protection, this opinion is supported by the Maliki School of jurisprudence. The Maliki School permitted Suftajah only when it is necessary or in conditions of extreme danger, especially for travelling merchants. Third, Suftajah is acceptable if the cost of transfer is minimal and small, if the cost of transfer is huge then it is not permissible. This opinion was supported by the Hanbali School jurisprudence. To sum up, the Maliki, Shafi'i, and Hanbali schools all strictly limit the use of suftajah (Ray, 1997).

\subsection{Al-Ibra}

The Arabic literal meaning of Al-Ibra is clearance or redemption and or to stay away from something. Ibra refers to "waiver on right of claim" (Bank Negara Malaysia, 2013), occurring when a creditor withdraws his or her right to collect debt. However, if a debt liability or right is not possessed by the creditor it is not regarded as Ibra. Ibra has two interpretations according to Islamic scholars; it encompasses the meaning of withdrawal of debt by the creditor and the meaning of transfer of ownership of debt to the debtor. The schools are divided based on these two interpretations. The Hanafi School upholds the meaning of withdrawal of debt and transfer of debt to the debtor, and based on this, the School stresses that Ibra is not applicable on Ayn (objects) because the ownership of objects cannot just be withdrawn but it remained instead under the ownership of its original landlord. Ibra is also not applicable on sold items, because the withdrawal of its ownership is not acceptable (Imam Ibn Qudama, 1968).

However, the Maliki School maintains the opinion that Ibra is a transfer of ownership which is based on the hibah (endowment) principle. The Shafii School is of the

International Journal of Management and Applied Research, 2019, Vol. 6, No. 4 
opinion that Ibra is an ownership given to the debtor on debt liability under his custody, therefore both debtor and creditor must be attentive to it, however some Shafii Scholars maintain that Ibra is a withdraw of debt liability to the debtor. The Hanbali School of the opinion that Ibra is a withdrawal of debt by creditor, and there is no objection to anybody who intends to withdraw his debt and convert it to an endowment, the Prophet talked to creditors to withdraw debt owed by Jabir (may Allah be pleased with him) (Imam Ibn Qudama, 1968).

Ibra is a mandub (recommended) act because it is kindness that includes the withdraw of debt owed by a debtor even if the debtor is not bankrupt, Allah the Almighty said: "And if debtor is in a hard time, then grant him time till it is easy for him to repay, but if you remit it by way of charity that is better for you did but know" (Qur' an Baqara, verse 280). Ibra is thus a charitable gratuitous contract and the provider of ibra is rewarded (Saleem, 2015).

\section{Islamic Capital Market}

The capital market is a financial market in which equity-backed securities or longterm debt are bought and sold. The contemporary capital market is also a medium for monetary policy transmission and the dissemination of market information. An Islamic capital market carries out all of these functions in a Shariah compliant manner (Archer and Karim, 2017). Like the capital market, Islamic capital market channels the wealth of individual savers to those who can transfer it to long-term productive use, such as companies or governments making long-term investments. However, the size of the Islamic capital market is smaller than the conventional one in terms of size. Mainly, this is due to the Shariah principles that prohibit the sale and purchase of interest-bearing debt as well as the emphasis on relating Islamic banking to the real economy (Jobst, 2007). Both financier and borrower share the investment risk together and their financial relationships are prohibited from investment in halal activities, namely gambling, speculative trade or exchange of money for debt without transfer of the underlying asset (Moriguchi et al., 2016). Financial certificates such as sukuk and debt certificate are used to raise funds from the public.

Debt and Sale of Debt: The Shariah Advisory Council in Malaysia accepts the principle of Bay' al dayn (debt trading) as one of the Islamic capital market instruments (Bank Negara Malaysia, 2010). Debt certificates such as Negotiable Islamic Debt Certificates and Negotiable Instruments of Deposits are designed as instruments for financial institutions to mobilise savings from the public.

Muqassah: Bilal and Meera (2015) proposed an Al-Muqassah model as an alternative Islamic credit card model for Islamic financial institutions. According to this model, both debtor and creditor must consent to muqassah (set-off), and each party should be a creditor and debtor at the same time. The financial institution will allocate and maintain a credit-line account to each individual customer. Although the implementation of such an Al-Muqassah model for retail banking is highly complicated, the idea of allowing both creditor and debtor to set off debt could be used in Islamic banking and finance at a corporate level. For example, companies which exist in a same supply chain could arrange for the Al-Muqassah model to set

International Journal of Management and Applied Research, 2019, Vol. 6, No. 4 
off debts. As for the implication for the Islamic capital market, Muqassah allows bankers and merchants to channel funding.

Suftajah: Suftajah is more commonly seen in the scattered historical references than in legal manuals and contemporary academic publications. Very few banks offer suftajah in modern times. The Kurdistan International Islamic Bank in Iraq is one of the examples. Originally developed and used by Arab merchants from the eighteen century, merchants were required to repay in the same currency without charging interest due to prohibition of riba under Shariah principles. Additionally, three schools of Islamic jurisprudence strictly limit the use of suftajah (Ray, 1997). All these factors discourage the use of suftajah in Islamic commerce. Nonetheless, suftajah marks the existence of an Islamic capital market in the early days where merchants and banks transfer surplus to those who need the funds to meet their short-term liquidity needs.

Hawalah: Although Hawalah resembles sale of debt, it is not a sale of debt (Saleem, 2015). Hawalah was permitted conditionally as a written instrument of credit by all schools of Islamic jurisprudence (Ray, 1997). Unlike suftajah, hawalah has been popular since Roman times and it is still being practised as a remittance system in modern days (Al Raisi et al., 2016). Hawalah does not contribute to the contemporary formal Islamic capital market but it allows the participating parties to engage in secondary trading of money and daily funding.

Ibra: The purpose of ibra (rebate) is to encourage paying debts in advance by giving monetary rewards. Ibra is a write-off mechanism that allows individuals to relinquish their rights to collect payment. Islamic jurists and scholars do not place restrictions on the conditions of relinquishment such as profit portion of the outstanding sale price (Archer and Karim, 2017). In 2011, Bank Negara Malaysia issued Guideline for Rebate (Ibra) for Sale-based Financing which make it mandatory for Islamic financial institutions in providing rebates under two scenarios: early settlement, default, restructuring into a new financing contract, and terminating the financing before maturity date. The main implication of ibra to the Islamic capital market is that, Islamic financial institutions are given the necessary funding to adjust their portfolios over a short term horizon.

\section{Conclusion}

It is understood that part of the reported traditions of the Prophet Muhammad indicate that debt should be avoided at all costs but Islamic scholars also recognise the need to borrow in the case of emergency and necessity. There is no contradiction between the two. According to the rules of Islamic Jurisprudence, the best thing is to integrate the two different approaches, if there is any diversification, and that will be applied by looking at the reasons why the prophet himself engaged in debt. Scholars of Islamic Jurisprudence demonstrated their opinion on this issue. The prophetic traditions which discourage debt are rooted in the tendency for non-repayment (Imam al-Dahawi, 1494). Islamic scholars emphasise the differences between unwillingness and inability to repay. The Prophet (SAW) said: "Whoever takes the money of the people with the intention of repaying it, Allah will repay it on his behalf, and whoever takes it in order to spoil it, then Allah will spoil him" (Sahih al-Bukhari, Book 43, Hadith 3).

International Journal of Management and Applied Research, 2019, Vol. 6, No. 4 
A person with debt cannot enter Jannah (paradise) when he or she dies. The scholars of Islamic jurisprudence share the consensus that debt testimony is compulsory before death (Ibn Abdul Bar, 1999). Debt or loan should only be undertaken in the case of necessity or emergency. Islam rules and Shariah principles as detailed in the Quran and hadith, guide Muslims how to make, save and borrow money in a socially responsible manner. The Islamic perspective on debt settlement discussed in this paper sheds some light on overcoming cash-flow problems and managing liquidity in compliance with Islamic law. Al-Muqassah models allow people to fulfill their financial needs without substantial interest charges by mutual setting-off of the debts (Bilal and Meera, 2015). Al-Hawalah, on the other hand, allows a debtor to transfer financial liability to another and it is commonly used in personal finance (Al Raisi et al., 2016) and business banking (Suhaimi et al. 2016). Ibra occurs when the creditors withdraw their rights to collect the debt from their debtors, typically in the case default and early settlement (Bank Negara Malaysia, 2013). And lastly, Suftajah is similar to a modern bill of exchange but the main difference is that, the payment must be made in the same currency.

\section{References}

1. Abubakar bin AbdulRazaq bin Hammam bin Nafi'I (1983), Kitab Al-Muasannaf, Lebanon: Alktab al-Islamy Bairut.

2. Abu Abdurrahman Ahmad bin Shuaib, bin Ali al-khrasani al-Nasa'i (1986), Maktab almudbu'at al-Islamiyyah, Syria: Halab.

3. Abu Abdallah, Ahmad bin Muhammad bun Ahmad Bin Hambal (2001), Kitab AlMusnad, Muassasat al-Risalah.

4. Abu Muhammad Abdallah bun Ahmad Ibn Qudamah (1968), Al-Muqni, Egypt: Maktabatul Qahirah.

5. Abu jafar ahmad bin Muhammad bin Salama bin Abdil malik al-azdi Al-Dahawi (1494), Sharh Mushkilul Athar, Muassasat al-risalah.

6. Al Raisi, A. K. S. D.; Rodriguez, I.; Tustikbayev, M.; Omarova, N.; Abdul Rahman, A. W.; Muneeza, A.(2016), "Implication of Hawālah in Islamic Finance Practice", International Journal of Management and Applied Research, Vol. 3, No. 3, pp. 109-119. https://doi.org/10.18646/2056.33.16-009

7. Archer, S. and Karim, R. A. A. (2017), Islamic Capital Markets and Products: Managing Capital and Liquidity Requirements Under Basel III, United Kingdom: John Wiley and Sons.

8. Bank Negara Malaysia (2010), Shariah Resolutions in Islamic Finance, $2^{\text {nd }}$ ed., [Online] Available from: http://www.bnm.gov.my/microsite/fs/sac/shariah_resolutions_2nd_edition_EN.pd $\underline{\text { f }}$ [Accessed on 17 October 2019].

International Journal of Management and Applied Research, 2019, Vol. 6, No. 4 
9. Bank Negara Malaysia (2013), Guidelines on Ibra' (Rebate) for Sale-Based Financing, Kuala Lumpur: Bank Negara Malaysia [Online] Available from: http://www.bnm.gov.my/guidelines/01 banking/04 prudential stds/Updated GL on Ibra Final Sept2013.pdf [Accessed on 4 June 2019].

10. Bhala, R. (2011), Understanding Islamic Law, Massachusetts: Lexis Nexis.

11. Bilal, M. and Meera, A. K. M. (2015), “Al-Muqassah model”, International Journal of Islamic and Middle Eastern Finance and Management, Vol. 8 No. 4, pp. 418-438. https://doi.org/10.1108/IMEFM-06-2014-0052

12. Ibn Abdul Bar. (1999), Kitab al-Tamhid, Egypt: Alfaruq al Hadith Publications.

13. Ibn Qayyim al-jawziyyah (1973), I'lam al-muwaqqien an rabbil alamin, Lebanon: dar al-jil Bayrut.

14. Imam Alauddin Abubakr Al-Kasani Alhanfi (2005), Badai' al-sani'i fi Tartib alSharai’i. Egypt: Darul Hadith Al-Qahirah.

15. Imam Al-Sarakhsi. (2001), Kitab Al-mabsud, Lebanon: Dar al-Kutub al-Ilmiyyah Beirut.

16. Imam Ahmad bin Shu'aib Abu Abdu Rahman Al-Nasa'i, (1986), Kitab al-Sunan, Maktab almadbuat al-Islamiyyah Halab.

17. Jobst, A. A. (2007), The Economics of Islamic Finance and Securitization: IMF Working Paper WP/07/117, International Monetary Fund, [Online] available from: https://www.imf.org/external/pubs/ft/wp/2007/wp07117.pdf [Accessed on 17 October 2019].

18. Moriguchi, T.; Khattak, M. A.; Farhan, M.; Firdaus, M.; Worasutr, A.; Hakim, A. L.; Musthafa, F.; Muneeza, A. (2016), "Contemporary Practices of Musharakah in Financial Transactions", International Journal of Management and Applied Research, Vol. 3, No. 2, pp. 65-76. https://doi.org/10.18646/2056.32.16-005

19. Muhammad bin Isma'il al-bukhari, (1987), Al-jami-al-sahih, Egypt: Dar Al-sha'b al-Qahirah.

20. Muhammad Amin bin Umar bin Abul Aziz Ibn Abideen (1992), Rad'almuhtaj, Lebanon: Darul Fikr Berut.

21. Ray, N, D. (1997), “The Medieval Islamic System of Credit and Banking: Legal and Historical Considerations", Arab Law Quarterly, Vol. 12, No. 1, pp. 43-90.

22. Saleem, M. Y. (2015), Islamic Commercial Law, Singapore: John Wiley and Sons, https://doi.org/10.1002/9781119198956.

International Journal of Management and Applied Research, 2019, Vol. 6, No. 4 
Debt Theories in Islamic Commercial Transactions and Its Implications on Islamic Capital Market

23. Sifat, I. and Mohamad, A. (2018), "From metal to paper: validating paper money from Islamic perspective", International Journal of Ethics and Systems, Vol. 34 No. 1, pp. 2-19. https://doi.org/10.1108/IJOES-06-2017-0090

24. Suhaimi, M. S. M.; Fauzi, M. S. M.; Noryatim, N.; Noh, N. M. Shuhaimin, N.; Jaafar, Q.; Maulan, S. M.; Johan, Z. F. and Muneeza, A. (2016), "Service Based Contracts Used in Islamic Finance: A Comparison of Hawalah, Wakalah, and Kafalah ", International Journal of Management and Applied Research, Vol. 3, No. 4, pp. 160-171. https://doi.org/10.18646/2056.34.16-013

International Journal of Management and Applied Research, 2019, Vol. 6, No. 4 